\title{
Implementation of Cooperative Learning Model in Preschool
}

\author{
Nilüfer Okur Akçay ${ }^{1}$ \\ ${ }^{1}$ Education Faculty, Ağrı İbrahim Çeçen University, Ağrı, Turkey \\ Correspondence: Nilüfer Okur Akçay, Education Faculty, Ağrı İbrahim Çeçen University, Ağrı, Turkey. \\ Tel: 90-536-897-4481. E-mail: nilokur-7@hotmail.com \\ Received: March 14, 2016 \\ Accepted: April 5, 2016 \\ Online Published: April 25, 2016 \\ doi:10.5539/jel.v5n3p83 \\ URL: http://dx.doi.org/10.5539/jel.v5n3p83
}

\begin{abstract}
In this study, the effectivity of jigsaw method, one of the cooperative learning models, on teaching the concepts related to sense organs and their functions to four-five year-old children in nursery class was analyzed. The study is in the semi-experimental design consisting of experimental and control groups and pretest and posttest. The sample of this study consists of 38 children from the nursery class of Ministry of National Education in Ağrı city center, in 2015-2016 academic years. Two groups determined randomly have been formed. These are: Jigsaw Group (JG, N=20) and Control Group ( $\mathrm{CG}, \mathrm{N}=18$ ). In the direction of the goals of this study, a data collection tool has been developed by the researcher to collect data. The test prepared by the researcher to determine the knowledge levels of the students about organs like ear, tongue, eye and skin and senses like hearing, smelling, tasting, seeing and sensing has been used. As a result of the obtained data, it has been determined that cooperative learning model is more effective in teaching the sense organs subject to the children compared to the traditional teaching method.
\end{abstract}

Keywords: preschool, cooperative learning, science teaching

\section{Introduction}

According to recent transnational evaluation results in the field of education (PISA, 2000-2015), our country should place more importance on education. Considering that the development level and education level of the countries are directly proportional, it is a must to give the necessary importance to each grade of education. Particularly, the preschool period in which our basic knowledge, skills and habits are formed is necessary for the individuals in the beginning of their lives to be more successful in their future grades (Aktas, 2009; Tugrul, 2005). This education process which is the first years of the life is quite important for the development and education of the child. Preschool education is actually the process which includes the period from birth to primary school and it aims to support the developments of the children at this age (Macaroğlu, 2004). The children in the preschool period in which their curiosity towards the world they live in starts to increase and their desire to get new information is quite intensive get new information by making investigation and they try to relate the cause and effect relationship by underlying the configuration of each new information with the information they've got (Kandır \& Orçan, 2010). When an individual is mostly active and open to learning is the first 3-6 years of his/her life. In this period, the individual has quite much energy and his/her perception level about what happens around is at its most (Küçükturan, 2003). Thus, the children in the preschool period should be given a good education to increase our country's education level.

\subsection{Cooperative Learning in Preschool}

Cooperative learning is a learning method in which the students help each other's learning about an academic subject in the classroom or in other environments by creating small mixed groups in the direction of a common goal, the self-confidence of the individuals increases, their communication skills improve, the students most actively participate in the lesson (Aykaç, 2005; Doymuş et al., 2005; Eilks, 2005; Gillies, 2006; Johnson et al., 1980; Johnson et al., 1998; Levine, 2001; Lin, 2006). Cooperative learning does not happen by creating an environment for the students to work together by dividing them into small groups. Basic features of cooperative learning are the studies which require that the students help each other's learning in the direction of a common goal, they solve the problems all together, everybody in the group have the right to talk, and they use the time well (Büyükkaragöz \& Çivi, 1997; Erdem, 2009). As the individuals are to work together, the behavior, helping each other, becomes prominent. During these cooperation activities, the students can utilize this process as a 
result of making courageous explanations to convey their opinions to other students about reorganizing the problem, explaining it and how to solve the problem (Eshietedoho, 2010; Hanze \& Berger, 2007; Stamovlasis et al., 2006; Zimmerman \& Gallagher, 2006). Thus, active learning methods in the education environments are being emphasized recently. With this method, it is aimed to raise students who are no longer loaded just with knowledge but they become individuals who can also use the knowledge they have got throughout their lives, think positively, can criticize, can be productive, explorer, creative and open to change. Thus, in today's education active learning methods should be included in teaching-learning activities as much as possible. Among these methods, one of the most used methods in recent years is the cooperative learning model (Stamovlasis et al., 2006). In the studies conducted on the students from all grades and different departments including preschool education, it was determined that cooperative learning methods are more effective on the student success compared to the traditional methods (Johnson \& Johnson, 1998; Yıldı, 1998; Marinopoulos \& Stavridou, 2002; Tarım \& Artut, 2004; Law, 2014; Chan, 2014; Akçay, 2014; Alp, 2015). As a result of the study, Askew and Wiliam (1998) emphasized that the positive effects of cooperative learning are independent from the age, skill levels of the students and the school types (state school, private school, etc.).

Cooperative learning method provides many conveniences to the students. The children get socialized by gaining favor for both themselves and their friends by entering the socializing environment brought along with the cooperating in the groups. Their sense of responsibility improves and their affective developments can increase by trying to be more active with the satisfaction of contribution to others. The individual can express their opinions through discussion, criticizing and conveying and also their communication skills improve and they gain the characteristics of a democratic. With this purpose, democratic individuals that our country needs are raised. Along with providing the social development and change of the individual (Büyükkaragöz \& Çivi, 1997), cooperative learning model also provides the students to develop a positive attitude towards the class (Demirtaş, 2008). Besides, while carrying out high level learning with cooperative learning model, the behaviors and attitudes of the students towards each other also improve. The students in the learning groups based on cooperation are to learn interpersonal or social skills with team spirit as a result of both academic and group studies (Saban, 2002). Divides these social skills into six groups. These are starting and maintaining a relationship skill, maintaining a group work skill, skills towards emotions, coping with aggressive behaviors skills, coping with stress skills, problem solving and planning skills. In cooperative learning, the students maximize both their and other student's learning (McHale, 2002). The goals of the students in cooperative learning is not to better than each other but to accomplish the better together (Nayan et al., 2010). Moreover, cooperative learning is a teaching and learning model which increases the motivation of the students, improves their thinking skills, makes the students respect each other's opinions, helps them learn to discuss between each, teaches them to become democratic individuals, prevent the teacher to be considered as the only teaching source and makes the teaching-learning environment to be entertaining for the students.

\subsection{Science Teaching in Preschool}

Science is the whole of knowledge which contributes significantly to the students' knowing about the world they live in by giving them the opportunity to analyze the nature and natural events is a process about analyzing the natural environment and is based on the systematic knowledge which is the result of this process. As each event in the nature is the subject of science, science is an important part of the life. Thus, science should be taught by relating it with the daily life. In this way, the children gain knowledge by encountering new information every day and they will relate this new information they've learnt with the old ones (Özbey, 2006; Aydoğan \& Şen, 2011).

Science teaching is given a considerable importance in the curriculums through which the preschool children can find answers to the questions about what happens around their environment. Science class is a course which helps the children understand and give meaning to what they see in their environment. According to Akgün (2004), the students who take science classes turn to individuals who are actively interested in the world, ask meaningful questions and collect data with experiments and analyze these, communicate in civilized way with others through verbal and written texts of what they've learnt, act with sense of responsibility and are aware of their responsibilities, are well-informed and skilled. According to Şimşek and Çınar (2008), it is important that particularly basic knowledge and skills should be taught during preschool period because it would be inevitable to find deficiencies in the later years even the children are equipped with a lot of knowledge and skills. Moreover, science activities in preschool period gain the children experiments such as high-level thinking skills, research, scientific experiments and scientific thinking skills (Bredekamp \& Copple, 1997). In this direction, science teaching should be given the necessary importance in preschool period and the teachers should be provided to have positive beliefs and attitudes towards it. 
Thanks to science teaching, the children have the opportunity to increase their knowledge through living and learning, improve their problem solving skills, know the features of the tools they can encounter in their daily lives. According to the results of several studies conducted on this subject (Ginsburg \& Golbeck, 2004; Patrick et al., 2009; Early et al., 2010), it is said that the children have the tendency to observe and think about nature and this tendency is gained during preschool period, also children's desire to learn science is higher than their desire to learn reading and writing, mathematics, art and social learning fields. Thus, learning opportunities should be correctly determined to give an effective science education to the children in preschool period (French, 2004). According to Kalley and Psillos (2001), basic science concepts start to be formed in the early childhood period which cover the first six years of life, in which physical, mental, emotional and social developments of the children is fast. So, the first planned and programmed education towards science takes place according to the children's interests and needs in preschool institutions. Thus, to support the children's developments in this way, the teachers should implement the science teaching by giving that the children the opportunity that they can observe, research, comprehend, test with active participation, bring forward their ideas, use their creativity and the teachers should consider the development levels, interests of the children, the opportunities of the environment and they should choose appropriate methods and techniques. Appropriate method is to be selected to teach the science concepts in the curriculum effectively to the children in preschool. According to Çetin et al. (2012), the methods to gain concept to the children should be presented concretely. In this direction, jigsaw method, one of the cooperative learning methods, has been used to gain the sense organs and senses subjects to the preschool children in this study. Cooperative learning is an appropriate method for the preschool children, it forms an infrastructure for future cooperative studies. It provides a great benefit to the children's learning in later grades. Cooperative activities are also important for the children to create awareness for others and develop their communication skills (Bayrakçeken et al., 2013). For this purpose, it has searched for answers to the following questions:

1) Does cooperative learning method have effects on the academic success of the children?

2) Is there a significant difference between the academic success of male and female students with the use of cooperative learning method?

\section{Method}

In this study, the effectivity of jigsaw method, one of cooperative learning models, on teaching the concepts related to sense organs and their functions to four and five year-old children in nursery class was analyzed. The study is in semi-experimental design with experimental and control groups and consists of pretest and posttest.

\subsection{Sample}

The sample of this study consists of 38 children from the nursery classes under Ministry of National Education in Ağrı city center in fall term of 2015-2016 academic years. Two groups consisting of children selected randomly have been formed. These have been determined as Jigsaw Group (JG, N=20) and Control Group (CG, $\mathrm{N}=18$ ).

\subsection{Data Collection Tools}

In the direction of the goals of this study, a data collection tools have been developed by the researcher to collect data. The tests prepared by the researcher to determine the knowledge levels of the students about organs like ear, tongue, eye and skin and senses like hearing, smelling, tasting, seeing and sensing have been used.

\subsection{Implementation Process}

In the implementation process of the study, traditional teaching method was used in the control group while the students in the experimental group was taught the sense organs with jigsaw method among cooperative learning models.

\subsubsection{Teaching through Cooperative Learning (Jigsaw)}

In the experimental group on which jigsaw method was implemented, four basic groups each of which consisted of five people was formed. A presentation about how to study, which subjects they would be responsible for and rules was done by the teacher. Then, each group was asked to determine a group name and a group leader for themselves. Parallel with the five-person groups in which the students would study, the Sense Organs subjects were collected under five titles as (1) Ear, (2) Nose, (3) Tongue, (4) Eye and (5) Skin. Then, the subjects were distributed to each student in the basic four groups consisting of five people and they were asked to research about the subject, learn and teach it to his/her group mates (see Figure 1). Besides, the teacher determined the materials related to the planned subjects and when needed, she/he undertook the guidance role to help the groups. 
Then, the students who studies the five titles from the basic groups were placed into jigsaw groups to present the subject to their friends who were responsible for other titles as A1, B1, C1, and D1 students into the first title (ear), A2, B2, C2, and D2 students into the second title (nose), A3, B3, C3, and D3 students into the third title (tongue), A4, B4, C4, and D4 students into the fourth title (eye), and A5, B5, C5, and D5 students into the fifth title (skin), which can be seen in Figure 1.

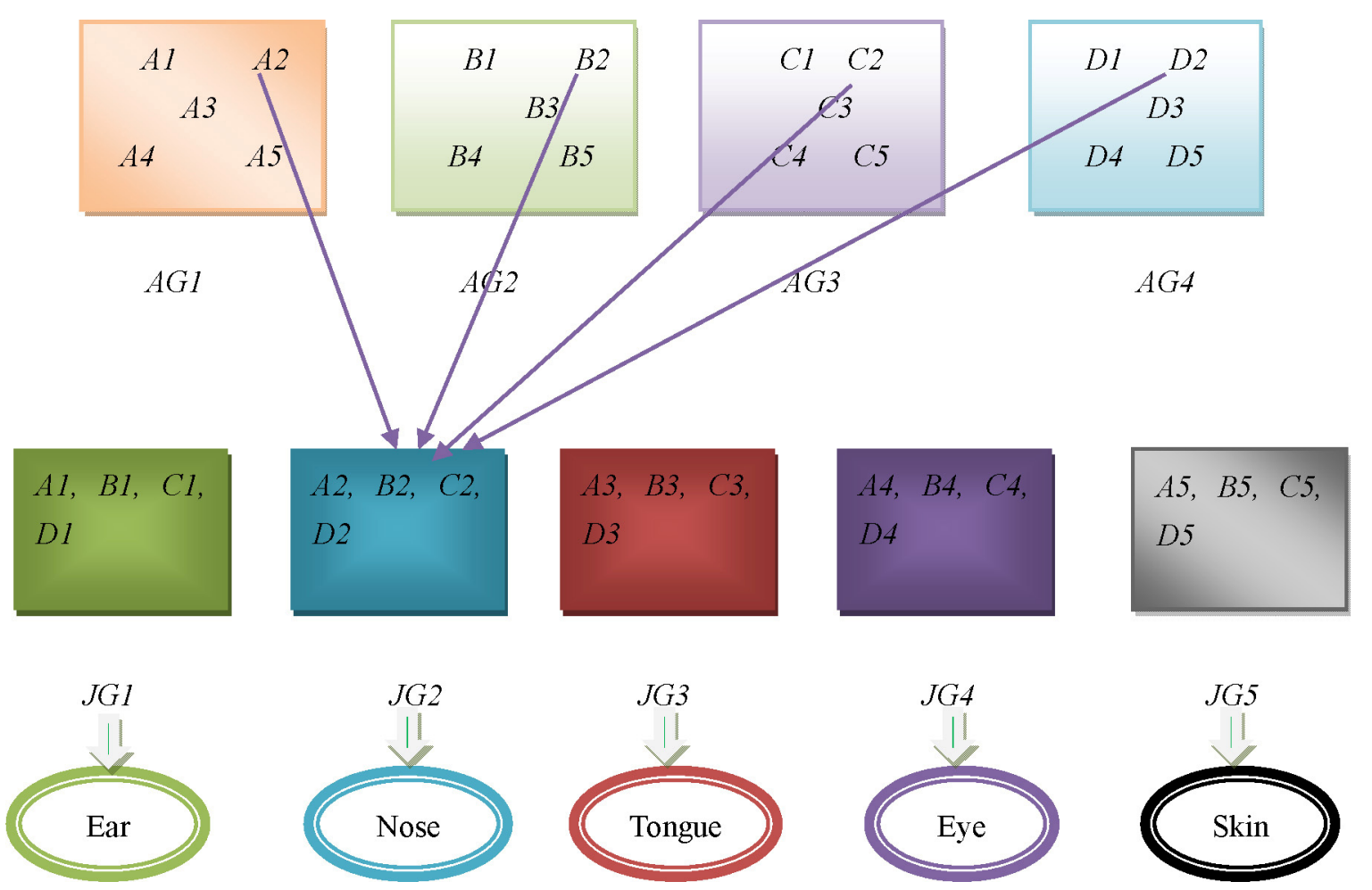

Figure 1. Forming jigsaw groups from the basic groups of the students whose groups were implemented the jigsaw method

The teacher provided the students in the group to bring other examples (pictures, tools, puzzles, toys, etc.) related to the given subjects from outside the classroom and to study together with their group mates. The teacher increased the students' curiosity with different experiments done by the students themselves and tried to make the groups to communicate with each other by encouraging the students to ask questions. During the implementation process, the group member gave examples to each other about the subjects they were responsible for and they started to perform roles all together when needed. In addition, different pictures were drawn based on the students' imagination and hung the best ones which was decided by themselves on the board together. In addition to these activities, games were played, riddles were asked and the course was conducted with the supervision and guidance of the teacher. With such a course, it was tried to provide the children to develop their social and cognitive characteristics. The children in the jigsaw groups were to expertise the subject by studying together with each other and prepared a product file with the help of the teacher to bring it to the main group. After each child returning to their main group had taught the subject they expertized for a week, they prepared a joint work together. For instance, attaching the mixed organs to a human model, painting them, placing the appropriate senses to the organs. By this means, all the groups were provided to learn the same things, different and imperfect learning was prevented.

\subsubsection{Teaching with Traditional Method}

While teaching the sense organ subjects in the class in which traditional teaching method was implemented, the teacher became a model for the children and the teacher himself decided what the children would do during the teaching process. The teacher planned the activities and made the children to do them. 


\section{Findings}

In this part of the study, the findings which were obtained as a result of the statistical analyzes of the obtained data are presented in tables and figures. The sample of the study is consisted of 12 females and 8 males in jigsaw group, 8 females and 10 males in control group. It can be seen that the gender distribution of the groups is close to each other. To determine the effectivity of the jigsaw method implemented within the study on teaching the sense organs subject, t-test results related to pretest and posttest scores which were implemented on JG and CG are indicated in Table 1.

Table 1. The independent t-test results of the data obtained from the sense organs achievement test

\begin{tabular}{lllllll}
\hline Tests & Groups & $\mathrm{N}$ & $\mathrm{X}$ & $\mathrm{ss}$ & $\mathrm{t}$ & $\mathrm{p}$ \\
\hline Pretest & JG & 20 & 1.70 & 1.34 & -1.21 & .233 \\
& $\mathrm{CG}$ & 18 & 2.22 & 1.30 & & \\
\hline Posttest & JG & 20 & 7.70 & 1.62 & 6.15 & .000 \\
& CG & 18 & 4.33 & 1.74 & & \\
\hline
\end{tabular}

As a result of the conducted analyzes, it was determined that the arithmetic mean of the pretest results of the experimental group was 1.70 and standard deviation was 1.34 ; the arithmetic mean of the control group was 2.22 and the standard deviation was 1.30 , and there was no significant difference between them $(\mathrm{t}(36)=-1.21 ; \mathrm{p}>0.05)$. It was determined that the arithmetic mean of the posttest results of the experimental group was 7.70 and the standard deviation was 1.62; the arithmetic mean of the control group was 4.43 and the standard deviation was 1.74 , and there was significant difference between them $(t(36)=6.15 ; \mathrm{p}<0.05)$. The fact that the age group of the children forming the sample of the study was younger, the socioeconomic level of the school environment was lower, the number of the educated parents was few are though to cause the children to get lower scores from the pretest. A child in normal development level is expected to learn and show when asked all the organs with the help of the parents but the children in the sample of this study were asked a few questions to determine their preparedness levels before implementing the pretest (like; can you show your tongue?) but no feedback was given. Thus, the data collection tools were not prepared according to the expected levels of the children but the observed levels of the children. A drawing which one of the students made is indicated in the figure below as an example.
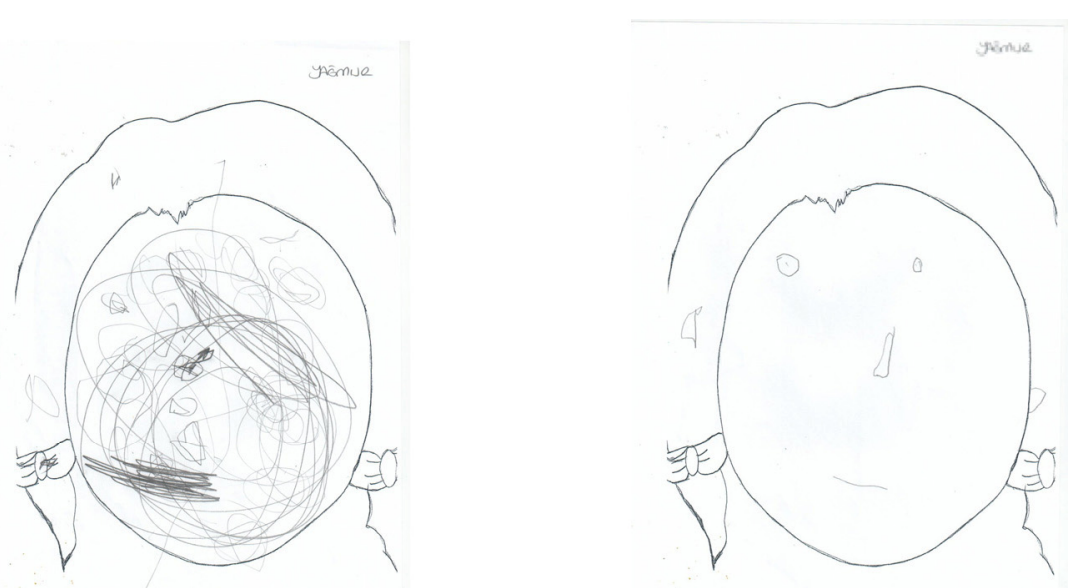

Figure 2. Pretest (left) and posttest (right) drawings of a student

As it can be seen in Figure 2 that the students drew none of the organs as stated but scratched in the pretest even though she/he was expected to draw eye-ear-nose-mouth and the teacher repeated these concepts many times. However, as a result of the implementation the same child did not scratch this time but tried to draw the desired 
organs despite non-proportionally. It is though that the children haven't gained the psychomotor characteristics completely because symmetric characteristics like big-small, up-down were observed in other children's drawings. Thus, the children who could not drew the organs in the same size or proportion were given full grades by the researcher.
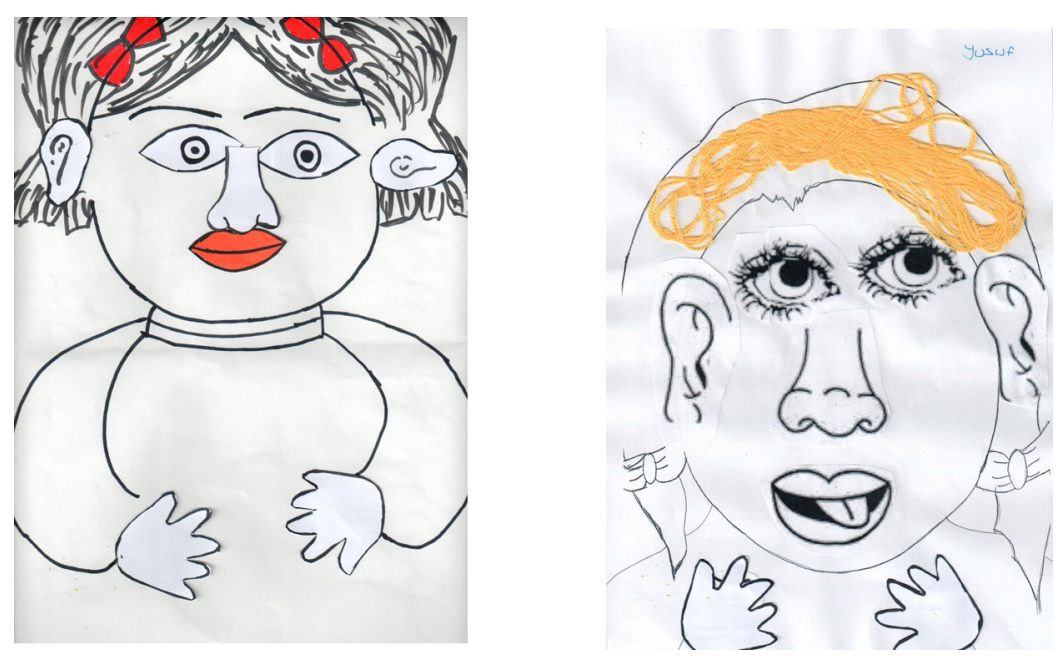

Figure 3. The test based on cut and paste which is used in the study

Because the psychomotor skills of the children observed within the study were not developed completely and the children could not do the drawings as desired, the researcher prepared an alternative test as seen in Figure 3 and the students were provided to do this prepared test. In this test which was prepared as cut-and-paste, the researcher cut the organs beforehand and put them in front of the students. And so, the children who could not hold the scissors or was able to hold the scissors but unable to cut properly were also helped. The children pasted the organs placed mixed in front of them into the places where they thought they would fit. Thus, it was tested whether the learning tool place or not. Another test prepared within the study was the matching the objects related to our sense of feeling, and it can be seen in Figure 4 that the children easily did this test.
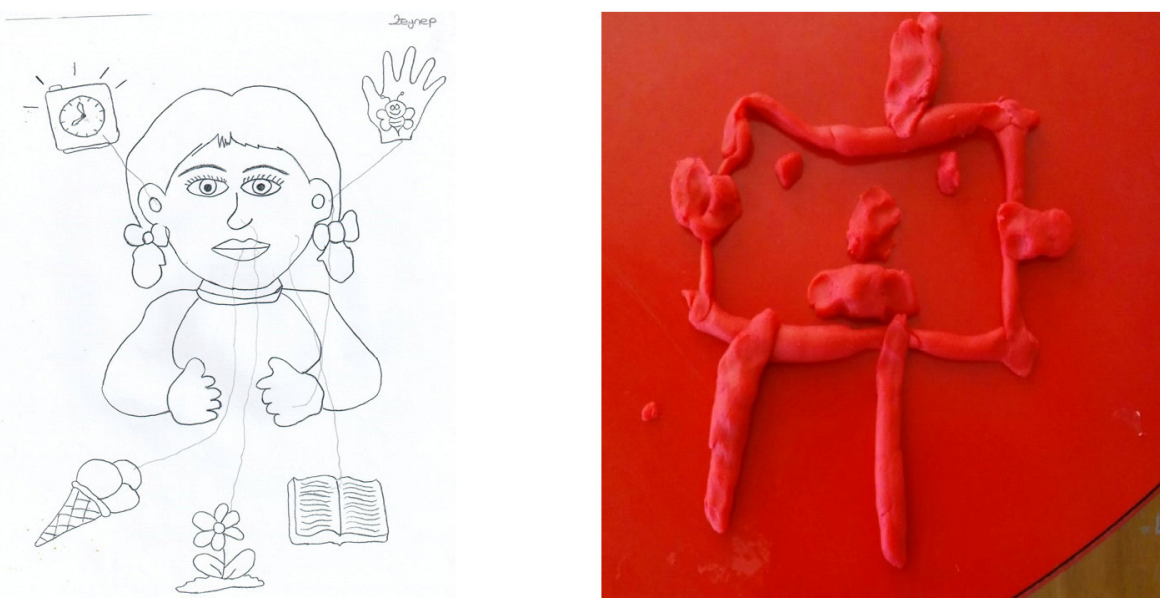

Figure 4. Play dough sample and matching test of one of the students in experimental group

As it can be seen in Figure 4, alarm clock as hearing, reading a book as seeing, ice cream as tasting, flower as smelling and hand examples as touching were given for each sense. It was thought that matching them with lines would be enough for the children. Hence, the children who learnt the subject well enough was observed to have 
no difficulties while matching. The children were asked to design sense organs with play dough within the study (see Figure 4). It was determined as a result of the observation done by the researcher that the children who used play dough in the experimental group had more fun and experienced the happiness of creating something altogether. The table below indicates the riddles that the students in the jigsaw group researched and taught to their friends.

Table 2. Riddle examples of the students in the jigsaw group related to sense organs

\begin{tabular}{|c|c|}
\hline Sense Organs & Riddles \\
\hline \multirow[t]{2}{*}{ Eye } & 1. I have two windows. Open in the morning, closed at night. \\
\hline & 2. I have two windows, covered with a wall of flesh. \\
\hline \multirow[t]{2}{*}{ Ear } & 1. Two spoons, attached on the walls. \\
\hline & 2. Flesh scale scales gold. \\
\hline \multirow[t]{2}{*}{ Nose } & 1. I have a well full of water. \\
\hline & 2. A well with a pillar, never dropping the water level. \\
\hline \multirow[t]{2}{*}{ Tongue } & 1. Sweeter than honey, hotter than poison. Prayer for the kinds. \\
\hline & 2. A peel in the bakery. \\
\hline Skin & $\begin{array}{l}\text { 1. If you stay under the sun more, it gets damaged, the biggest organ of } \\
\text { our body actually. }\end{array}$ \\
\hline
\end{tabular}

Different experiments were also done in the jigsaw group with the help of the teacher. For example, the children smelled different smells with their eyes blindfolded and they were asked to guess which object the smell belonged to. With the intent of emphasizing the importance of the ear, music was listened and the children were asked to close one of their ears and ear health was emphasized by mentioning the difference in between. Rough and smooth surfaces were prepared and the children provided to touch and feel these surfaces.

In addition to that, the children in the jigsaw group brought toys and materials to the classroom and they made effort for their friends to understand better. Example materials are indicated in the figure below.
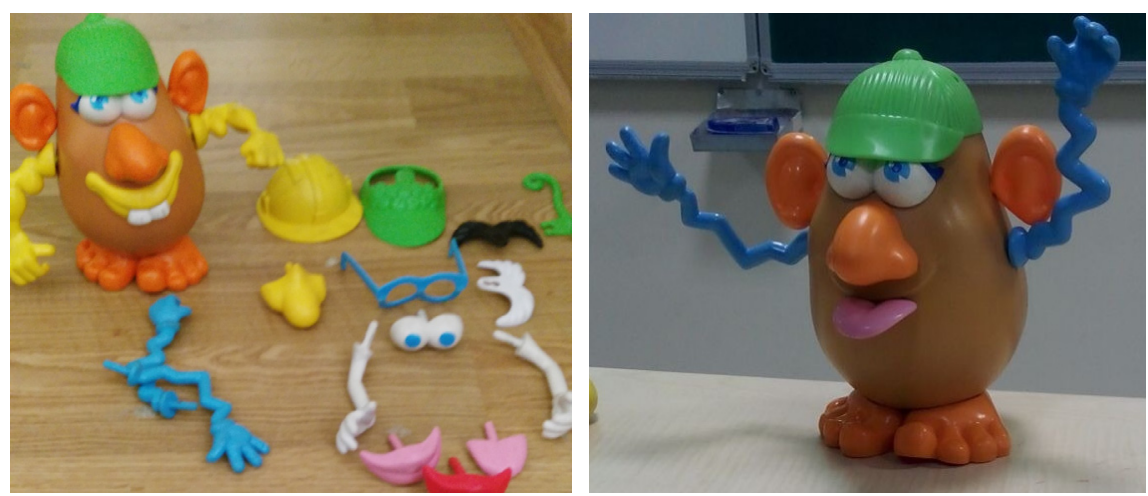

Figure 5 . The toy bought by a student in the jigsaw group from his/her home

Table 3 indicates whether there is a significant difference among the children in terms of gender. 
Table 3. The pretest-posttest independent t-test results of the female and male students

\begin{tabular}{lllcccc}
\hline Tests & Groups & $\mathrm{N}$ & $\mathrm{X}$ & $\mathrm{ss}$ & $\mathrm{t}$ & $\mathrm{p}$ \\
\hline Pretest & Female & 20 & 2.10 & 1.44 & \multirow{2}{*}{.739} & .465 \\
& Male & 18 & 1.77 & 1.21 & & \\
Posttest & Female & 20 & 6.65 & 2.15 & \multirow{2}{*}{1.51} & .139 \\
& Male & 18 & 5.50 & 2.52 & \\
\hline
\end{tabular}

As it can be seen in Table 2, it was determined the arithmetic mean of the pretest results of the female students was 2.10 and the standard deviation was 1.44; the arithmetic mean of the male students was 1.77 and the standard deviation was 1.21 , and there is no significant difference between them $(\mathrm{t}(36)=.739 ; \mathrm{p}>0.05)$. It can be said that there is no difference in terms of the preparedness levels of the students. It was determined that the arithmetic mean of the posttest results of the female students was 6.65 and standard deviation was 2.15; the arithmetic mean of the male students was 5.50 and the standard deviation was 2.52 , and the difference between them was not significant $(\mathrm{t}(36)=1.51 ; \mathrm{p}>0.05)$. In this direction, it can be concluded that gender variable has no effect on learning the subject.

\section{Results and Discussion}

In this study, it was aimed to analyze the effectivity of cooperative learning model on teaching the sense organs subject as a science subject which was aimed to be taught to children continuing preschool. Before starting the implementation, it was found that there was no significant difference between the achievement test scores of two groups obtained from the pretest about sense organs subject $(p>0.05)$, there was a significant difference between the achievement test scores obtained from the posttest $(p<0.05)$ and this difference was on behalf of the experimental group. According to the obtained results, it is seen that cooperative learning model is more effective on teaching the sense organs subject to the students compared to the traditional teaching method and it can be seen in the literature that implementing cooperative learning model increases the quality of the education (Yıldız, 1998; Veenman et al., 2002). Cooperative learning model can be applied to any age groups successfully and teaching with cooperative learning provides the students social addiction and the students play a role in increasing each other's success as a group (Artut \& Tarım, 2004; Doymuş et al., 2005). The students should study in a way that they can be in communication with each other in the implementation of cooperative learning model (Kagan \& Kagan, 2009). Below is the figure showing that the experimental group students are in an order appropriate to the cooperative learning model within this study.

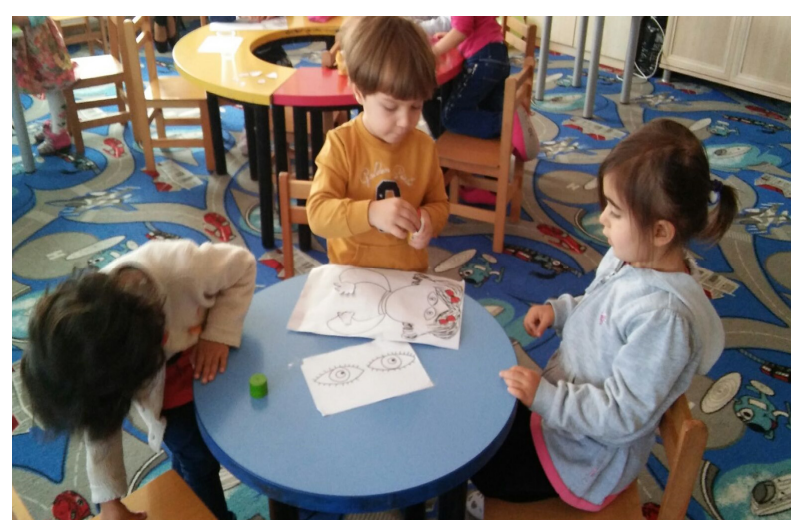

Figure 6. Jigsaw group students

It was determined during the study with the observation of the researcher that a number of social skills were developed in the students on whom the cooperative learning model was implemented, the communication of the students who had difficulty in terms of communication and even introvert students with their friends increased, the sense of responsibility of the students was developed, the children were motivated to actively fulfill their tasks. As a matter of fact, in his study, Avcioğlu (2003) stated that cooperative learning model is effective on the preschool children's learning the listening skills, verbal explanation skills and interpersonal skills. Tarım and Artut (2004) who determined that the cooperative learning model is effective on the students' success and 
improves the students' social skills like positive talking stated that cooperative learning model is a method which can be implemented in preschool education. In this direction, considering the fact that using different methods and techniques in teaching of the subjects provides a more effective learning, it can be said that the preschool teachers should use different methods and techniques in their classes. Accordingly, for a teacher to achieve a learning which is not based on memorization, she/he should know the methods and techniques which help to understand the cognitive structures of the students and she/he should implement these in his/her classes (Önen, 2005; Y1lmaz \& Çolak, 2011). According to Manning and Lucking (1991), the teacher in cooperative learning is considered to be the one who creates a teaching and learning environment and the process in which both the teacher and the student consider each other as a learning source. Thus, the preschool teachers should be informed of organizing and implementing this process. Johnson et al. (1990) who stated that the preparations before the implementation is as important as the implementation and some criterions should be determined for the children think that especially the teachers should determine the social skills they will teach in the class, they should list the skills (such as respect, adopting the task, participating in the activity, encouraging friends, staying within the group, talking undertone, etc.) that can positively affect the group study process and they should be used in the evaluation of the children. In the study done by Alp (2015) with preschool children to decrease the social adaptation problems, it was determined that cooperative learning model is an effective method to eliminate social adaptation problems, it encourages the children for problem solving, it makes remembering and comprehending the concepts easier, it provides to transfer and share what's been learnt. As a result of this study, it can be concluded that cooperative learning can be implemented easily in the preschool education by the preschool teachers considering that cooperative learning has many positive benefits. In the conducted studies (Avcioğlu, 2003; Artut \& Tarım, 2004; Tarım \& Artut, 2004), it is stated that cooperative learning methods can be used starting from preschool period.

\section{References}

Akçay, N. O. (2014). The effect of learning together method on teaching contrast concepts. Journal of Research in Education and Teaching, 3(1), 398-405.

Aktaş, Y. A. (2009). Okulöncesi dönemde matematik öğretimi (4. basım). Adana: Nobel Kitabevi.

Akkök, F. (1999). İlköğretimde sosyal becerilerin geliştirilmesi ögretmen el kitabı. İstanbul: Özgür Yayınevi.

Akgün, Ş. (2004). Fen bilgisi öğretimi. Ankara: PegemA Yayınc1lık.

Alp, H. (2015). Okul öncesi dönem çocuklarda sosyal uyum problemlerinin düzeltilmesinde işbirliki öğrenme yöntemi ve oyun etkinliklerinin etkisi. Akademik Bakış, 51, 88-101.

Artut, P. D., \& Tarım, K. (2004). Okulöncesi kubaşı öğrenme uygulamaları: Toplama işlemine yönelik bir uygulama örneği. Çukurova Üniversitesi Sosyal Bilimler Enstitüsü Dergisi, 13(2), 1-10.

Askew, M., \& Wiliam D. (1998). Recent Research in Mathematics Education 5-16. London: H.M.Stationery Office.

Avcıoglu, H. (2003, October). Okulöncesi dönemdeki çocuklara sosyal becerilerin ögretilmesinde is birlikçi ögrenme yöntemi ile sunulan ögretim programinin etkililiginin incelenmesi. Paper presented at OMEP 2003 World Council and Conference, Kuşadası, Turkey.

Aykaç, N. (2005). Öğretme ve öğrenme sürecinde aktif öğretim yöntemleri (1. Baskı). Ankara: Naturel Yayıncilik.

Aydoğan, S. A., \& Şen, S. (2011). 6 yaş çocuklarının sayı kavramının gelişiminde kavram eğitim programının etkisinin incelenmesi. Adnan Menderes Üniversitesi Ĕ̆itim Fakültesi Ĕgitim Bilimleri Dergisi, 2(1), 38-51.

Bredekamp, S., \& Copple, C. (1997), Developmentally appropriate practice in early childhood programs (revised edition). Washington, DC: NAEYC Publishing.

Bayrakçeken, S., Doymuş, K., \& Doğan, A. (2013). İşbirlikli öğrenme modeli ve uygulanması. Ankara: Pegem Akademi Yayıncılık.

Büyükkaragöz, S., \& Çivi, Ç. (1997). Genel öğretim metotları. İstanbul: Özel Eğitim Yayınları.

Çetin, T., Yavuz, S., Tokgöz, B., \& Güven, G. (2012). Okul öncesi dönemdeki çocuklara (60-72 ay) uzay kavramlarının öğretimi. GUJGEF, 32(3), 715-731.

Chan, K. W. (2014). Cooperative learning in a Hong Kong primary school: Perceptions, problems and accommodation. Intercultural Education, 25(3), 216-228. http://dx.doi.org/10.1080/14675986.2014.911805 
Demirtaş, F. (2008). İşbirlikli öğrenmenin öğrenci tutumlarına etkisi (Unpublished master thesis). Abant İzzet Baysal University, Social Sciences Institute, Bolu.

Doymuş, K., Şimşek, Ü., \& Şimşek, U. (2005). İşbirlikli öğrenme yöntemi üzerine derleme: Işbirlikli öğrenme yöntemi ve yöntemle ilgili çalışmalar. Erzincan Eğitim Fakültesi Dergisi, 7(1), 59-83.

Early, D. M., Iruka, I. U., Ritchie, S., Barbarin, O. A., Winn, D. C., Crawford, G. M., ... Pianta, R. C. (2010). How do pre-kindergarteners spend their time? Gender, ethnicity and income as predictors of experiences in pre-kindergarten classrooms. Early Childhood Education Quarterly, 25, 177-193. http://dx.doi.org/10.1016/j.ecresq.2009.10.003

Eilks, I. (2005). Experiences and reflections about teaching atomic structure in a jigsaw classroom inlower secondary school chemistry lessons. Journal of Chemical Education, 82(2), 313-319. http://dx.doi.org/10.1021/ed082p313

Erdem, A. (2009). Preservice teachers' attitudes toward cooperative learning in mathematics course. Procedia-Social and Behavioral Science Journal, 1(1), 1688-1672. http://dx.doi.org/10.1016/j.sbspro.2009.01.295

Eshietedoho, C. G. (2010). The effects of cooperative learning methods on minority ninth graders in earth and space science (Unpublished $\mathrm{PhD}$ thesis). Nova Southeastern University, USA.

French, L. (2004). Science as the center of a coherent, integrated early childhood curriculum. Early Childhood Research Quarterly, 19(1), 138-149. http://dx.doi.org/10.1016/j.ecresq.2004.01.004

Gillies, R. M. (2006). Teachers' and students' verbal behaviours during cooperative and small-group learning. British Journal of Educational Psychology, 76(2), 271-287. http://dx.doi.org/10.1348/000709905X52337

Ginsburg, H. P., \& Golbeck, S. L. (2004). Thoughts on the future of research on mathematics and science learning and education. Early Childhood Research Quarterly, 19(1), 190-200. http://dx.doi.org/10.1016/j.ecresq.2004.01.013

Kalley, M., \& Psillos, D. (2001). Pre-school teachers' content knowledge in science: Their understanding of elementary science concepts and of issues raised by children's questions. International Journal of Early Years Education, 9(3), 165-179.

Hanze, M., \& Berger, R. (2007). Cooperative learning, motivational effects and student characteristics: An experimental study comparing cooperative learning and direct instruction in 12th grade physics classes. Learning and Instruction, 17(1), 29-41. http://dx.doi.org/10.1016/j.learninstruc.2006.11.004

Johnson, D. W., Johnson, R. T., \& Holubec, E. J. (1990). Circles of learning: Cooperation in the classroom. MN: Interaction.

Johnson, D. W., Skon, L., \& Johnson, R. (1980). Effects of cooperative, competitive and individualistic conditions on children's problem-solving performance. American Educational Research Journal, 17(1), 83-93. http://dx.doi.org/10.3102/00028312017001083

Johnson, D. W., Johnson, R. T., \& Holubec, E. J. (1998). Cooperation in the Classroom. Edina, Minnesota: Interaction Book Company.

Kagan, S., \& Kagan, M. (2009). Kagan cooperative learning. San Clemente: Kagan Publishing.

Kandır, A., \& Orçan, M. (2010). Okul öncesi dönemde matematik eğitimi. İstanbul: Morpa Kültür Yayınları.

Küçükturan, G. (2003). Okul öncesi fen öğretiminde bir teknik: Analoji. Milli Ĕgitim Dergisi, 157.

Law, Y. K. (2014). The role of structured cooperative learning groups for enhancing Chinese primary students' $\begin{array}{lllll}\text { reading comprehension. } & \text { Educational } & \text { Psychology, } & 34, & \text { 70-494. }\end{array}$ http://dx.doi.org/10.1080/01443410.2013.860216

Levine, E. (2001). Reading your way to scientific literacy. Journal of College Science Teaching, 31(2), 122-125.

Lin, E. (2006). Cooperative learning in the science classroom. The Science Teacher, 73(5), 34-39.

Macaroğlu, A. E. (2004). Fen ve doğa etkinlikleri. İstanbul: Morpa Kültür Yayınları.

Manning, M. L., \& Lucking, R. (1991). The what, why, and how of cooperative learning. The Clearing House, 64(3), 152-156. http://dx.doi.org/10.1080/00098655.1991.9955832

McHale, M. (2002). Cooperative learning in an elementary physical education program. Journal of Physical Education, Recreation \& Dance, 73(7), 20-23. http://dx.doi.org/10.1080/07303084.2002.10607840 
Marinopoulos, D., \& Stavridou, H. (2002). The influence of a collaborative learning environment on primary students' conceptions about acid rain. Journal of Biological Education, 37(1), 18-25. http://dx.doi.org/10.1080/00219266.2002.9655841

Nayan, S., Shafie, L. A., Mansor, M., Maesin, A., \& Osman, N. (2010). The practice of collaborative learning among lecturers in malaysia. Management Science and Engineering, 4(1), 62-70.

Önen, F. (2005). İlköğretimde basinç konusunda öğrencilerin sahip olduğu kavram yanılgılarının yapılandırmacı yaklaşımla giderilmesi (Unpublished master thesis). Marmara University, Educational Sciences Institute, İstanbul.

Özbey, S. (2006). Okul öncesi eğitim kurumlarında görev yapan öğretmenlerin fen etkinliklerine ilişkin yeterliliklerinin belirlenmesi (Unpublished master thesis). Gazi University, Educational Sciences Institute, Ankara.

Patrick, H., Mantzicopoulos, P., \& Samarapungavan, A. (2009). Motivation for learning science in kindergarten: Is there a gender gap and does integrated inquiry and literacy instruction make a difference. Journal of Research in Science Teaching, 46(2), 166-191. http://dx.doi.org/10.1002/tea.20276

Saban, A. (2002). Öğrenme öğretme süreci yeni teori ve yaklaşımlar (2. Bask1). Ankara: Nobel Yayıncılık.

Stamovlasis, D., Dimos, A., \& Tsaparlis, G. (2006). A study of group interaction processes in learning lower secondary physic. Journal of Research in Science Teaching, 43(6), 556-576. http://dx.doi.org/10.1002/tea.20134

Şimşek, N., \& Çınar, Y. (2008). Okul öncesi dönemde fen ve teknoloji öğretimi. Ankara: Anı Yayıncılık.

Tarım, K., \& Artut, P. D. (2004, July). Anasınıfi ögrencilerine toplama ve çıkarma becerilerinin kazandırılmasında kubasık ögrenme yönteminin uygulanması. Paper presented at 1. International Preschool Congress, İstanbul.

Tuğrul, B. (2005). Çocuk gelişiminde anaokulu eğitiminin önemi. Bilim ve Aklın Aydınlı̆̆ında Eğitim Dergisi, 62, $1-3$.

Veenman, S., Van Benthum, N., Bootsma, D., Van Dieren, J., \& Van der Kemp, N. (2002). Cooperative learning and teacher education. Teaching and Teacher Education, 18(1), 87-103. http://dx.doi.org/10.1016/S0742-051X(01)00052-X

Yıldız, V. (1999). İşbirlikli öğrenme ve geleneksel öğretimin okulöncesi çocuklarının temel matematik becerilerinin gelişimi üzerindeki etkileri. Education \& Science, 23(111), 42-50.

Yılmaz, K., \& Çolak, R. (2011). Kavramlara genel bir bakıs: Kavramların ve kavram haritalarının pedagojik açıdan incelenmesi. Atatürk Üniversitesi Sosyal Bilimler Enstitüsü Dergisi, 15(1), 185-204.

Zimmerman, D. K., \& Gallagher, S. R. (2006). Creativity and team environment: An exercise illustrating how much one member can metter. Journal of Management Education, 30(4), 617-625. http://dx.doi.org/10.1177/1052562905282017

\section{Copyrights}

Copyright for this article is retained by the author(s), with first publication rights granted to the journal.

This is an open-access article distributed under the terms and conditions of the Creative Commons Attribution license (http://creativecommons.org/licenses/by/3.0/). 